\title{
ОСОБЛИВОСТІ СОЦІАЛЬНОЇ ПЕРЦЕПЦІЇ У СТУДЕНТСЬКОЇ МОЛОДІ (ГЕНДЕРНИЙ АСПЕКТ)
}

\section{Демянюк Олена Богданівна \\ Старший викладач кафедри практичної психоло- гії та психотерапії Рівненського державного гуманітарного університету, Рівне (Україна)}

\section{Косарева Оксана Іванівна}

Кандидат педагогічних наук, доиент кафедри педагогіки і психологї (дошкільної та корекиійної) імені проф. Т. І. Поніманської Рівненького державного гуманітарного університету, м. Рівне (Украӥна)

\begin{abstract}
Анотація. В статті висвітлено гендерні особливості соціальної перцепції $у$ студентської молоді. Термін «соціальна периееція» у загальному вигляді означає формування $у$ свідомості людини образу іншого. Зміст поняття включає сприймання не тільки фізичних властивостей об'єкта, а також його внутрішніх характеристик: намірів, думок, здібностей, емоиій, установок, ичінностей тощчо. Доведено, щэо існує зв'язок між такими гендерними характеристиками особистості, як фемінність, маскулінність, андрогінність та соціальною перцепиією. Для представників обох статей є притаманними гендерні сочіальні стереотипи $i$ установки, які, з одного боку, базуються на гендерних особливостях, а з іншого - підкріплюючись сочіальним оточенням, призводять до прояву щее більших гендерних відмінностей в сприйманні оточуючого світу, щзо в свою чергу може призводити до непорозумінь та конфліктів між чоловіками та жінками.
\end{abstract}

Ключові слова: сочіальна перцепиія, гендерні стереотипи, студентська молодь.

Постановка проблеми. Сучасне суспільство характеризується істотними трансформаціями в соціальній сфері, найважливішими 3 яких можна вважати зниження значущості соціальної стратифікації, підвищення інтересу до індивідуальності кожної людини та визнан- ня багатогранності, рівноцінності різних соціальних груп. На сучасному етапі питання про психологічні відмінності чоловіків і жінок стає особливо значущим, оскільки відповіді на нього формують підгрунтя для конкретних практик в соціальній, правовій та культурній 
сферах. Залишаються актуальними питання вивчення як загальних закономірностей і механізмів гендерної диференціації, так і конкретних іiі відображень в структурі особистості. Образи світу чоловіків і жінок характеризуються особливостями, що детерміновані специфікою актуальної гендерної ситуації та відображенням в свідомості особистості індивідуальної картини світу.

У сучасній науці гендерний підхід до аналізу соціальних, культурних процесів i явищ використовується дуже широко. В соціально-психологічних дослідженнях розглядається, які ролі, норми, цінності, риси характеру культивує суспільство щодо жінок і чоловіків через системи соціалізації, розподілу праці, культурні цінності та символи.

Традиційно, під словом стереотип розуміють якусь схему (кліше), на основі якої відбувається сприйняття і оцінка інформації. Ця схема виконує функцію узагальнення певного явища, предмета або події, з іiї допомогою людина діє або здійснює оцінку автоматично. Поняття соціального стереотипу означає здатність людини узагальнено оцінювати навколишній світ і $є$ підставою для ії висновків. Позитивна функція соціальних стереотипів полягає в тому, що, діючи в умовах дефіциту інформації, вони дозволяють швидко реагувати на зміни, які відбуваються, прискорюють процес пізнання. Однак далеко не завжди соціальний стереотип є відображенням об'єктивної реальності. Часто стереотипи здійсню- ють консервативний вплив, формуючи в людях помилкові знання і уявлення, які, в свою чергу, негативно позначаються на процесах міжособистісної взаємодії. Узагальнення характеристик окремих індивідів і поширення їх на групу людей і явищ називається стереотипізацією [5].

Зазначена проблема $\epsilon$ актуальною, оскільки представники обох статей все активніше займаються діяльністю, яка раніше була для них закрита через соціальні стереотипи, що призводило до порушення розподілу «чоловічих» i «жіночих» ролей. Такі зміни призводять до неминучих конфліктів, попередження і розв'язання яких потребує знань гендерної психології. Розробка даного питання є важливою у зв'язку із необхідністю подолання численних гендерних стереотипів, що поширені у сучасному світі, відтак формують ригідність мислення та поведінки у представників чоловічої і жіночої статі. Розв'язання даної проблеми забезпечує впровадження принципу рівності усіх громадян, закріпленого у статті 24 Конституції України.

\section{Аналіз останніх досліджень і публі-} кацій. Роль соціальної перцепції в життєдіяльності людини знайшла відображення у багатьох працях вітчизняних і зарубіжних дослідників. Зокрема, вивчалися соціальноперцептивні характеристики спільної діяльності (Г. Андреєва, А. Коссаковски, М. Обозов, Х. Теджфел, С. Фрейзер, П. Шихирев, А. Юревич); механізми соціальної перцепції, 
що обумовлюють ефективність взаємодії людей (В. Агеєв, О. Бодальов, І. Кон, Т. Хайдер, В. Ядов); проблеми підвищення точності міжособистісного сприймання, розвитку соціальної перцепції (А. Бандура, М. Герберт, М. Даннет, К. Девіс, О. Донцов, Г. Келлі, Дж. Кемпбелл, К. Левін, 3. Фрейд); особливості міжособистісного сприймання в різних сфеpax життєдіяльності, спілкування людини (Л. Гозман, Я. Коломінський, С. Максименко, М. Пірен, В. Семиченко, В. Циба, Н. Чепелєва, Ю. Швалб). Термін «соціальна перцепція» був запропонований Дж. Брунером. У загальному вигляді він означає формування у свідомості людини образу іншого. Дослідження соціальної перцепції зосереджені на вивченні двох блоків проблем: аналізі особливостей суб'єкта й об'єкта міжособистісного сприймання й аналізі його механізмів. Соціальна перцепція $\epsilon$ передусім пізнавальним процесом. Невід'ємною частиною будь-якого соціальноперцептивного процесу $\epsilon$ емоційномотиваційний та поведінковий аспекти життєдіяльності особистості. Зміст поняття «соціальна перцепція» включає сприймання не тільки фізичних властивостей об'єкта, а також його внутрішніх характеристик: намірів, думок, здібностей, емоцій, установок, цінностей тощо [5].

Статеві та гендерні відмінності досліджувались в достатньо широкому спектрі: від зоопсихології (Н. Тих) і психофізіології
(А. Ярмоленко,
Н. Розе,
Л. Головей,

Л. Сауліна, В. Сєргєєва) до соціальної психології (А. Бодальов, В. Куніцина, І. Кон, Н. Обозов, Е. Чугунова, В. Панферов, С. Міхеєва, В. Лосенков). На сучасному етапі проводяться дослідження в таких областях: статево-рольові стереотипи (В. Агєєв), рольова структура молодої сім'ї (С. Антонюк), гендерна соціалізація (І. Клєцина), формування психосексуальної культури молоді (Л. Гридковець), самоактуалізація особистості в професії - гендерний аспект (Л. Ожигова), гендерні установки (В. Каган), гендерна психологія лідерства (Т. Бендас), стереотипи жіночої поведінки (О. Мітіна, В. Петренко) та ін. Серед сучасних досліджень також варто виділити праці О. Азарової, С. Скорнякової, Н. Шведової, О. Ярославкіної, В. Арістова та ін. Попри різноманітність досліджуваних напрямів проблема гендерних відмінностей соціальної перцепції у студентської молоді ще не отримала на сьогодні достатнього висвітлення.

Метою статті $є$ висвітлення результатів експериментального дослідження гендерних особливостей соціальної перцепції у студентської молоді.

\section{Виклад основного матеріалу дослі-} дження 3 обгрунтуванням отриманих наукових результатів. Базою дослідження були студенти Рівненського державного гуманітарного університету. Сукупна чисельність студентів в дослідженні склала 60 осіб: 30 юнаків та 30 дівчат - студенти 3, 4 та 5 курсів денної 
форми навчання. Вік досліджуваних - від 19 до 23 років.

Під час проведення дослідження був застосований опитувальник С. Бем з вивчення маскулінності-фемінності, який використовується 3 метою виявлення гендерних проявів в поведінці особи [2]. Зазначена вище методика базується на гіпотезі, сформульованій С. Бем, про існування 3 типів людей з різною гендерною ідентичністю: 3 переважанням фемінних характеристик, 3 переважанням маскулінних характеристик і андрогенних характеристик, тобто осіб, в яких спостерігається баланс маскулінних і фемінних ознак. Прийнято виділяти гендерно типові якості (маскулінні - для чоловіків, фемінні - для жінок), гендерно атипові (маскулінні - для жінок, фемінні - для чоловіків) та гендерно нейтральні (характерні для обох статей). У відповідності до рівня прояву даних ознак, особистість відносять до однієї з 5 груп: яскраво виражена маскулінність, маскулінність, андрогінність, фемінність, яскраво виражена фемінність.

Для безпосереднього вивчення гендерних відмінностей в сприйманні реальності використовувалась методика вивчення показів свідків А. Коні (Варіант 2 «Одяг») [1]. Методика спрямована на дослідження соціальної перцепції, шляхом отримання свідчень досліджуваних про зовнішність людей з їх близького оточення. В нашому дослідженні використовувалась методика в модифікації Т. Бендас, згідно 3 якою, обстежуваним пропонується залишити приміщення (в нашому випадку аудиторію), а далі по черзі заходити і повернувшись спиною до присутніх описати свого сусіда (сусідку) по парті - як вони сьогодні одягнені, яка в них зачіска, прикраси, макіяж тощо. При інтерпретації враховувалась детальність опису, кількість помилок, кількість правильно вказаних деталей, називання незначних, непримітних на перший погляд деталей.

В дослідженні використовувався також «Опитувальник гендерних установок і стереотипів», що складається 3 переліку запитань, спрямованих на визначення гендерних установок і стереотипів, наявних у представників чоловічої та жіночої статі [4].

За результатами дослідження маскулінності-фемінності було встановлено, що найбільший процент обстежуваних жінок відноситься до категорії фемінність - 36,6 \%. Для значної кількості досліджуваних жіночої статі характерною є яскраво виражена фемінність $\mathrm{i}$ андрогінність (відповідно 19,8 \% і 29,7 \%). Також наявний певний відсоток жінок з ознаками маскулінності - 13,2 \%. Серед досліджуваних представниць жіночої статі не виявлено жодної, якій була б притаманна яскраво виражена маскулінність.

Отже, на підставі отриманих результатів, можна припустити, що для більшої частини жіночої статі, швидше за все, притаманні такі фемінні риси, як емоційність, м'якість, чуйність, комунікативність, сензитивність, здатність до емпатії, вразливість, безпосеред- 
ність i пасивність, щиросердність, емоційність, інтуїтивність. Але для певної кількості жінок характерним є поєднання як жіночих, так і чоловічих рис, або, навіть, переважання останніх.

Щодо результатів, отриманих в дослідженні представників чоловічої статі за опитувальником фемінності-маскулінності, то в більшості з них було виявлено приналежність до категорії маскулінність і яскраво виражена маскулінність (відповідно 42,9 \% і 16,5\%). Значна кількість чоловіків належать до категорії андрогінність - 23,1%. Фемінність притаманна для $16,5 \%$ опитуваних чоловіків. Також не виявлено жодного представника чоловічої статі, якому була б притаманна яскраво виражена фемінність.

Відтак, на основі отриманих даних можна припустити, що для переважаючої частини чоловічої статі притаманні такі маскулінні риси, як незалежність, активність, допитливість, схильність до ризику, авторитарність, агресивність, надмірний раціоналізм, безкомпромісність, наполегливість, розвинута мотивація досягнення, ініціативність, високий інтелект і свобода від стереотипів. Але для певної кількості чоловіків характерним є поєднання як чоловічих, так і жіночих рис, або навіть переважання останніх.

Під час проведення методики «Вивчення показань свідків» А. Коні (Варіант 2 «Одяг») серед представників чоловічої статі не було виявлено жодного, хто б виконав пос- тавлене завдання в повному обсязі. Тобто жоден 3 чоловіків не дав точного опису зовнішнього вигляду особи, про яку запитувалось. Також у відповідях досліджуваних чоловіків була відсутня деталізація - вони не вказували дрібниці в одязі, макіяжі, прикрасах тощо, які на перший погляд не кидалися у вічі, хоча були досить суттєвими. Лише 13,2 \% чоловіків дали достатній опис зовнішності своїх одногрупників, тобто вони в більшості випадків правильно вказували, який саме одяг був одягнений на них, якого він був кольору. Іноді, навіть, були правильно вказані особливості макіяжу та прикраси, але лише в тих випадках, коли вони були яскравими і привертали увагу.

Оцінку «задовільно» опису зовнішнього вигляду іншої людини отримали 23,1 \% обстежуваних представників чоловічої статі. Дана частина досліджуваних більш-менш точно давала характеристику зовнішності особи, про яку запитувалось, але в загальних рисах, в їх описі не вказувалось жодної деталі. Вони також не змогли правильно відповісти на уточнюючі запитання про певні деталі одягу, наявність візерунків на ньому та інші другорядні ознаки зовнішнього вигляду. Найбільша кількість чоловіків, які брали участь у дослідженні, дали поверхневий опис особливостей зовнішнього вигляду своїх одногрупників (39,6 \%). Вони лише в дуже загальних рисах змогли описати в чому була одягнена особа, про яку запитували, причому часто в їх відпо- 
відях траплялися неточності та помилки. В їхньому описі повністю були відсутні будь-які деталі, вони не змогли вказати хоч якісь особливості макіяжу, і часто неправильно вказували колір одягу.

Не в повному обсязі описали зовнішній вигляд тієї особи, про яку запитувалось, або взагалі не могли вказати, як сьогодні виглядала певна людина 23,1 \% досліджуваних чоловіків. Тобто ця частина представників чоловічої статі взагалі не мала уявлення про зовнішній вигляд людей, які належать до їх близького оточення, і з якими вони перед проведенням дослідження провели практично цілий день. Деякі чоловіки, що входять до цієї категорії, надзвичайно дивували аудиторію, коли при описуванні зовнішності якоїсь особи, вони вказували зовсім протилежні речі, ніж ті, які були насправді. Наприклад, один 3 досліджуваних сказав, що його одногрупниця одягнена у щось сіре, хоча насправді на ній була яскраво червона кофта і блакитні джинси. Ще в іншому випадку обстежуваний сказав, що волосся однієї з дівчат хвилясте, розпущене i спадає їй нижче плечей, а в дійсності у зазначеної особи волосся на голові було високо зібране у хвіст, причому закріплене величезною яскравою прикрасою.

Такий результат, отриманий у представників чоловічої статі щодо рівня розвитку в них соціальної перцепції, швидше за все, можна пояснити тим, що чоловіки більше уваги звертають на те, що пов'язане 3 технікою (наприклад, деякі 3 досліджуваних чоловіків в точності описували мобільний телефон і називали його модель в тієї особи, про зовнішній вигляд якої запитували), а не на інформацію, яка має відношення до особистості об'єкта сприймання. А також чоловіки, зазвичай, не надають значної уваги невербальним ознакам та стимулам.

Щодо аналізу результатів дослідження представниць жіночої статі за методикою «Вивчення показань свідків» А. Коні (Варіант 2 «Одяг»), то в даному випадку повністю виконали поставлене завдання 29,7 \% жінок. Опис даної частини обстежуваних відзначався абсолютною точністю і деталізацією. Вони повністю описували зовнішній вигляд особи, про яку запитувалось, включаючи всі деталі одягу, його кольору, візерунки на ньому, зачіску, прикраси, особливості макіяжу тощо. Причому деякі з них вказували навіть такі деталі, як колір лаку для нігтів чи гудзиків на сорочці.

Найбільша кількість досліджуваних жінок (39,6 \%) дала достатній опис зовнішності своїх одногрупників, який був досить точним і містив в собі опис основних деталей зовнішнього вигляду. Тобто, при описі особи, про яку запитувалось, жінки в більшості випадків правильно вказували, який одяг був на ній, основні кольори одягу, зазначали яскраві прикраси та деталі.

На задовільному рівні описали зовнішній вигляд запропонованої особи 19,8 \% пред- 
ставниць жіночої статі. Ця частина досліджуваних спромоглась вказати лише загальні риси зовнішності іншої людини, будь-які деталі в їх описі були відсутні. В більшості випадків вони акцентували свій опис на одній-двох складових, які привернули їх увагу і запам'яталися. Наприклад, вказували, що на особі, про яку запитувалось, була одягнена туніка коричневого кольору і темні чобітки, але не могли пригадати, що під туніку були одягнені брюки, і тим більше не пам'ятали якого вони кольору.

Поверхневий опис особливостей зовнішності своїх одногрупників здійснили 9,9 \% жінок. Вони лише в загальних рисах змогли описати, в чому була одягнена особа, про яку запитували, причому часто в їх відповідях траплялися неточності та помилки. В їхньому описі повністю були відсутні будь-які деталі, вони не змогли вказати хоч якісь особливості макіяжу, і часто не зовсім вірно вказували колір одягу. Серед обстежуваних представниць жіночої статі не було жодної, яка б зовсім неправильно описала зовнішній вигляд особи, про яку запитувалось, або ж взагалі не могла вказати, як сьогодні виглядала певна людина. Всі жінки без виключення змогли назвати хоча б декілька характеристик зовнішності своїх одногрупників.

Зазначені результати дослідження жінок можна пояснити особливостями розвитку властивостей уваги у представниць жіночої статі. Також це може пояснюватися більшим інтересом жінок до інформації, що стосується особистості людини, та кращою короткочасною пам'яттю. Відтак, жінки вважаються більш надійними свідками.

На наступному етапі дослідження ми порівняли результати дослідження представників чоловічої і жіночої статі за обома методиками. Всі відповіді обстежуваних за методикою А. Коні за рівнем якості можна умовно поділити на 3 рівні: високий, середній і низький.

На високому рівні завдання виконали 25 досліджуваних. 3 них фемінні риси було виявлено у 28,2 \% (12 жінок, 5 чоловіків), андрогінні - у 18,26 \% (8 жінок, 3 чоловіків). На цьому рівні не виявлено жодного респондента 3 маскулінними характеристиками.

Середній рівень соціальної перцепції виявили у 21,6 \% обстежуваних. Серед них $8 \%$ мають фемінні характеристики особистості (5 жінок), 7\% - андрогінні характеристики (1 жінка, 3 чоловіка), 5\% - маскулінні (1 жінка, 2 чоловіків).

Решта 36,5 \% досліджуваних показали низький рівень розвитку соціальної перцепції. В дану категорію не увійшло жодного обстежуваного 3 фемінними рисами, $1,7 \%$ - 3 андрогінними рисами (1 чоловік), та $31,5 \%$ - 3 маскулінними (3 жінки, 16 чоловіків).

Отже, аналізуючи дані, які були отримані нами в результаті співставлення показників досліджуваних, можна зробити висновок, що дійсно існує зв'язок між такими гендерни- 
ми характеристиками особистості, як фемінність, маскулінність, андрогінність та сприйманням оточуючого світу, зокрема, соціальною перцепцією. Було виявлено, що вона краще розвинена у осіб, для яких притаманні фемінні властивості особистості, та досить добре розвинена у андрогінних людей. Особи, яким характерні маскулінні властивості, мають в більшості випадків нижчий рівень розвитку соціальної перцепції.

Такі результати можна пояснити, швидше за все, тим, що фемінність - це властивість особистості, що передбачає відповідність поведінки, статево-рольових нормам, цінностям, установкам, притаманним жіночій статі. Разом $з$ тим, для жіночої статі $є$ притаманна перевага в довільній увазі, в вибірковості, стійкості та обсязі уваги та краща короткочасна пам'ять. Андрогінність - це поєднання чоловічих і жіночих рис. Тому високий та середній рівень розвитку соціальної перцепції показали в основному лише ті чоловіки, для яких були притаманні фемінність та андрогінність.

Аналіз результатів Опитувальника гендерних установок і стереотипів засвідчив, що найтиповішим для обох статей $є$ стереотип, згідно з яким головою сім ї обов'язково повинен бути чоловік. Переконаність в цьому факті характерна для більшості досліджуваних чоловіків (79,7 \%) та жінок (59,8\%). Таку свою позицію досліджувані в основному пояснювали тим, що чоловік забезпечує сім'ю, за- робляє гроші і краще вирішує проблеми, а завдання жінки - лише підтримувати його в цьому, не втручатися і не заважати.

Проте, 29,9 \% жінок відповіли, що чоловік і жінка повинні мати рівні права в управлінні сімейними справами, а 9,9 \% навіть сказали, що «головою» в сім’і повинна бути виключно жінка. Щодо чоловіків, то схильність до рівноправ'я в сім'ї виявило лише 19,9\%. Відтак, яскраво помітний вплив загальноприйнятого стереотипу, що склався в суспільстві, ніби забезпечувати сім'ю і отримувати значний дохід може лише представник чоловічої статі, а жінка повинна займатися господарством і вихованням дітей.

Заслуговує на увагу також той факт, що зазначений стереотип практично не відповідає реальній ситуації в родині батьків досліджуваних обох статей. Лише в 49,8 \% чоловіків і 34,9 \% жінок батько дійсно є «головою» сім'ї. Решта 49,8 \% чоловіків та 39,9 \% жінок повідомили, що головною в їх родині є мати, а також 24,9 \% жінок відповіли, що у них в сім’і панує рівноправ'я. Тобто в дійсності гендерні стереотипи не завжди є реально обгрунтованими.

Певні відмінності були помічені при аналізі того, в яких ознаках чоловіки і жінки вбачають «головування» в сім'ї. На думку представників чоловічої статі головним в родині є той, хто керує справами сім’ї, все вирішує, управляє бюджетом, має емоційне та інтелектуальне домінування, кому належить 
останнє слово у вирішенні різноманітних питань.

Жінки ж вважають, що «головування» проявляється у відповідальності, прийнятті важливих рішень, забезпеченні сім’ї, наявності влади, веденні господарства, авторитетності, управлінні бюджетом, організації дозвілля, керуванні. Тобто для чоловіків «голова» сім’ї в основному - це той, хто має владу, керує, домінує, для жінок - той, хто найкраще справляється з обов'язками організації життєдіяльності родини.

Також нами була перевірена наявність в представників різних статей установки на те, хто буде головним в їхній майбутній родині. Як з'ясувалось, 54,9 \% чоловіків і 64,8 \% жінок переконані, що в сім’ї, яку вони створять, буде головним чоловік, 24,9 \% чоловіків i 34,8 \% жінок погоджуються на рівноправ'я в майбутній сім “̈, а 19,8 \% чоловіків бажають, щоб головною в родині була жінка, пояснюючи це тим, що «нинішні дівчата такі, що їм скільки не говори, а вони все-одно будь стояти на своєму і зроблять так, як самі захочуть. Нехай жінка буде головною, я краще не буду їй суперечити» (серед жінок такої тенденції не спостерігалося).

Ми намагалися також 3'ясувати, чи притаманний для представників різних статей стереотип, щодо існування таких якостей особистості, які притаманні виключно жінкам та чоловікам. Було виявлено, що практично всі представники чоловічої та жіночої статей ма- ють такий стереотип. Зокрема, чоловіки до суто жіночих рис відносять такі: лагідність, стриманість, доброта, співчуття, аналізування, милосердя, сексуальність, вірність, комунікабельність, здатність йти на компроміс, емоційність, охайність, сентиментальність, відповідальність, чутливість, гламурність, поступливість, впевненість, строгість, економність, емпатійність, вередливість, раціональність, мудрість, слабкість.

Жінки віднесли до виключно жіночих рис такі, як: ніжність, чуйність, покірність, кокетливість, сексуальність, турботливість, емпатійність, доброта, допитливість, лагідність, відповідальність, наївність, сентиментальність, вірність, мрійливість, поступливість, м'якість, терплячість, манірність, сором'язливість, егоїзм, чутливість, емоційність, комунікабельність, спокій, скромність і здатність до співчуття.

Щодо виключно чоловічих рис особистості, то чоловіки вказали наступні якості: наполегливість, мужність, відповідальність, мудрість, сміливість, хоробрість, фізична сила, зухвалість, прислухання до думки інших, енергійність, цілеспрямованість, непередбачуваність, довірливість, терплячість, вірність, дбайливість, впевненість, лідерство.

Жінки визначили такі суто чоловічі риси: мужність, відповідальність, сила, впевненість в собі, раціональність, «холодний» розум, відвага, витривалість, дбайливість, авторитетність, цілеспрямованість, власність, су- 
ворість, наполегливість, рішучість, стриманість, грубість, зосередженість, сміливість, винахідливість, самостійність, агресивність.

Лише 6,8 \% досліджуваних відповіли, що суто жіночих чи суто чоловічих рис немає; що чоловіки володіють всіма тими якостями, що і жінки, і навпаки; що представники обох статей в однаковій мірі можуть проявляти будь-які якості особистості.

Отже, отримані результати свідчать, що і жінки, і чоловіки мають яскраво виражені установки і стереотипи щодо рис, які можуть $i$ повинні бути притаманними представникам кожної статі та $є$ соціально бажаними і очікуваними. На це вказує і той факт, що чоловіки i жінки називали практично однакові якості, що притаманні певній статі, тобто відповідали згідно зі стереотипами, нав'язаними їм суспільством ще з самого дитинства.

До якостей, які є однаково притаманні для чоловіків і жінок, досліджувані чоловіки віднесли: доброту, розуміння, розсудливість, лабільність, спонтанність, непередбачуваність, ніжність, мужність, відповідальність, повагу до партнера, строгість, впертість, ревнивість, поступливість, егоїзм, турботливість.

Жінки серед цих якостей вказали такі: ніжність, впертість, вірність, цілеспрямованість, розсудливість, чесність, відповідальність, пунктуальність, терплячість, почуття гумору, акуратність, впевненість, наполегливість, лагідність, уважність, турботливість, доброзичливість, людяність, романтичність, стриманість, рішучість, тактовність, доброта, довіра, мудрість, ініціативність.

Також ми досліджували, чи наявні гендерні стереотипи в представників обох статей щодо «ідеального» чоловіка і жінки. Ідеальна партнерша, на думку чоловіків, повинна володіти такими якостями, як розуміння, поступливість, вірність, привабливість, відданість, відсутність ревнощів, спокійність, лагідність, повага, доброзичливість, підтримка, терплячість, відкритість, раціональність, надійність, розумність. Причому 24,9 \% чоловіків зазначили, що їх партнерша і так є ідеалом у всіх відношеннях.

Ідеальний партнер, на думку жінок, має володіти наступними якостями: уважність до дрібниць, надійність, вірність, чесність, почуття гумору, розум, цілеспрямованість, доброта, терплячість, впевненість, мужність, воля, відвертість, ініціативність, дотримання слова, краса, певна агресивність, відсутність шкідливих звичок, харизма, серйозність, ніжність, поступливість, романтичність, достаток, відкритість, співчуття, тактовність, мудрість, готовність допомогти, розуміння, підтримка. Про наявність реального ідеального партнера вказали 19,9 \% жінок.

Аналізуючи зазначені вище списки «ідеальних» якостей, можна зауважити, що чоловіки називали переважно фемінні риси особистості, які повинні бути в партнерші в ідеалі, а жінки - загалом утворили портрет андрогінної особистості, як ідеал чоловіка. 
Можливо, це пов'язано 3 тим, що чоловіки більш схильні дотримуватись соціально бажаної поведінки, проявляти ті реакції, які будуть схвалені соціумом, а для жінок не встановлені такі жорсткі рамки і вони можуть проявляти меншу гендерну стереотипність.

Висновки. Отже, за результатами дослідження ми встановили, що дійсно існує зв'язок між такими гендерними характеристиками особистості, як фемінність, маскулінність і андрогінність та соціальною перцепцією. Нами було виявлено, що соціальна перцепція краще розвинена у осіб, яким притаманні фемінні якості особистості, та досить добре сформована у андрогінних людей. Особи, яким характерні маскулінні властивості, за підсумками нашого дослідження, мають в більшості випадків нижчий рівень розвитку соціальної перцепції. Було встановлено, що серед студентської молоді гендерні установки та стереотипи є досить поширеними. Зокрема, найтиповішими для обох статей є стереотипи, згідно 3 якими головою сім ї повинен бути чоловік.

Для представників обох статей є притаманними гендерні соціальні стереотипи і установки, які, з одного боку, базуються на гендерних особливостях, а з іншого - підкріплюючись соціальним оточенням, призводять до прояву ще більших гендерних відмінностей в сприйманні оточуючого світу, що в свою чергу може призводити до непорозумінь та конфліктів між чоловіками та жінками.

Перспективу подальших розвідок вба- чаємо у апробації корекційної програми, спрямованої на розширення знань про гендерні особливості, корекцію стереотипів і установок, формування гендерної культури міжстатевого спілкування.

\section{Перелік використаних джерел:}

1. Бендас Т. В. Гендерная психология: Учебн. пособие /

Т. В. Бендас. - СПб.: Питер, 2008. - 431 с.

2. Ильин Е. П. Дифференциальная психофизиология мужчины и женщины / Е.П. Ильин. - СПб.: Питер, $2003-544$ c.

3. Петренко О. Б. Гендерна психологія. Практикум / О.

Б. Петренко. - Рівне: РДГУ, видавець Олег Зень, 2012. - 127 c.

4. Практикум по гендерной психологии /Под ред. И. С. Клециной. - СПб.: Питер, 2003. - 479с.

5. Психологічна енциклопедія / [авт.-упоряд. О.М. Степанов] - К.: Академвидав, 2006. - 424 с.

\section{References (Transliteration):}

1. Bendas T. V. Gendernaya psihologiya: Uchebn. posobie / T. V. Bendas. - SPb.: Piter, 2008. - $431 \mathrm{~s}$.

2. Ilin E. P. Differentsialnaya psihofiziologiya muzhchinyi i zhenschinyi / E.P. Ilin. - SPb.: Piter, 2003 - 544 s.

3. Petrenko O. B. Genderna psyhologia. Praktykum / O. B. Petrenko. - Rivne: RDGU, vydavets Oleg Zen, 2012. $127 \mathrm{~s}$.

4. Praktikum po gendernoy psihologii /Pod red. I. S. Kletsinoy. - SPb.: Piter, 2003. - 479s.

5. Psyhologichna entsyklopediya / [avt.-uporyad. O.M. Stepanov] - K.: Akademviyav, 2006. - 424 s.

(C) Демянюк О. Б., Косарєва О. I. 


\section{Demianiuk Olena}

Assistant Professor of The Department of Practical Psychology and Psychotherapy, Rivne State Humanitarian University, Rivne (Ukraine)

\section{Kosareva Oksana}

PhD (Pedagogical Sciences), Assistant Professor of T. I. Ponimanska Department of Pedagogy and Psychology (preschool and correction), Rivne State Humanitarian University, Rivne (Ukraine)

\section{CHARACTERISTICS OF STUDENT'S SOCIAL PERCEPTION (GENDER ASPECT)}

\section{ABSTRACT}

The article highlights the gender features of social perception of student youth. Today, the problem is topical because both sexes are increasingly engaged in activities that were previously closed to them because of certain social stereotypes of "male" and "female" roles distribution. It leaded to inevitable conflicts; thus, prevention and resolution of them requires knowledge of gender psychology. The development of this issue is important due to the necessity of overcoming numerous gender stereotypes prevalent in the modern world. They form rigid thinking and behaviour of males and females. Generally, the term "social perception" means how people think about other people, how they form impressions, draw conclusions, and try to explain other people's behaviour. The content of the concept includes the perception of not only external but also internal characteristics of an object, namely intentions, thoughts, abilities, emotions, attitudes, values, etc.

The study was conducted in Rivne State
University of Humanities. The total number of students took part in the study - 60 people (30 boys and 30 girls), the students of the third, fourth, and fifth courses of full-time education. The age of the subjects was from 19 to 23 years. We used the Bem Sex Role Inventory (BSRI) to identify gender manifestations in person's behaviour. For the direct study of gender differences in social perception, we used the method of examining witnesses by Anatoliy Koni (Option 2 "Clothes") and "The Questionnaire for Gender Settings and Stereotypes".

Our study proved the connection between femininity, masculinity, androgyny and social perception. We found that social perception is better developed in persons with feminine qualities and quite well formed in androgynous persons. Masculine persons, according to the results of our study, showed a lower level of social perception development in most cases. Gender stereotypes appeared to be quite common among students; the most common for both sexes is the one, according to which a man should be the paterfamilias.

Both sexes demonstrated gender social stereotypes and settings, which, on the one hand, are based on gender peculiarities and, on the other hand, are supported by social environment. They lead to deeper gender differences in the perception of the world around, which in turn may lead to misunderstandings and conflicts between males and females. 
Key words: social perception, gender stereotypes, student youth.

\section{Демянюк Елена Богдановна}

Старший преподаватель кафедры практической психологии и психотерапии Ровенского государственного гуманитарного университета, Ровно (Украина)

\section{Косарева Оксана Ивановна}

Кандидат педагогических наук, доиент кафедры педагогики и психологии (дошкольной и коррекционной) имени проф. Пониманской Т.И. Ровенского государственного гуманитарного университета, Ровно (Украина)

\section{ОСОБЕННОСТИ СОЦИАЛЬНОЙ ПЕРЦЕПЦИИ У СТУДЕНЧЕСКОЙ МОЛОДЕЖИ (ГЕНДЕРНЫЙ АСПЕКТ)}

Аннотация. В статье проанализированы гендерные особенности социальной перцепции у студенческой молодежи. Проблема актуальна, поскольку представители мужского и женского пола все активнее занимаются деятельностью, которая ранее была для них закрыта через социальные стереотипы, что приводило к нарушению распределения «мужских» и «женских» ролей. Такие изменения приводят к неизбежным конфликтам, предупреждение и решение которых требует знаний гендерной психологии. Разработка данного вопроса является важной в связи с необходимостью преодоления многочисленных гендерных стереотипов, которые распространены в современном мире, поэтому формируют ригидность мышления и поведения у представителей мужского и женского пола. Термин «социальная перцепция» в общем виде означает формирование в сознании человека обра- за другого. Содержание понятия включает восприятие не только физических свойств объекта, а также его внутренних характеристик: намерений, мыслей, способностей, эмоций, установок, ценностей.

Базой исследования были студенты Ровенского государственного гуманитарного университета. Совокупная численность студентов в исследовании составила 60 человек: 30 юношей и 30 девушек - студенты 3, 4 и 5 курсов дневной формы обучения. Возраст испытуемых - от 19 до 23 лет. При проведении исследования был применен опросник С. Бем по изучению маскулинности-феминности, который используется для выявления гендерных проявлений в поведении человека. Для непосредственного изучения гендерных различий в социальной перцепции использовалась методика изучения свидетельских показаний А. Кони (Вариант 2 «Одежда»). Также был использован «Опросник гендерных установок и стереотипов».

Доказано, что существует связь между такими гендерными характеристиками личности, как феминность, маскулинность, андрогинность и социальной перцепцией. Нами было выявлено, что социальная перцепция лучше развита у лиц, обладающих феминными качествами личности, и достаточно хорошо сформирована у андрогинных личностей. Респонденты, которым характерны маскулинные свойства, по итогам нашего исследования, имеют в большинстве случаев ниже уровень 
развития социальной перцепции. Было установлено, что среди студенческой молодежи гендерные установки и стереотипы являются довольно распространенными. В частности, типичными для представителей мужского и женского пола является стереотипы, согласно которым главой семьи должен быть мужчина.

Для представителей обоих полов присущи гендерные социальные стереотипы и установки, которые, с одной стороны, базируются на гендерных особенностях, а с другой подкрепляясь социальным окружением, приводят к проявлению еще больших гендерных различий в восприятии окружающего мира, что в свою очередь может приводить к недоразумениям и конфликтам между мужчинами и женщинами.

Ключевые слова: социальная перцепция, гендерные стереотипы, студенческая молодежь. 